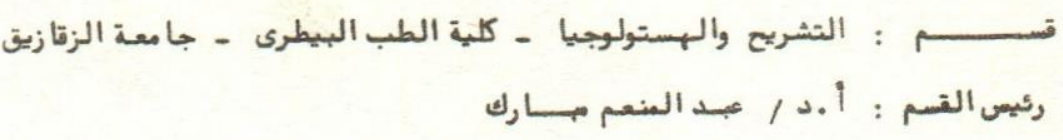

طوبغرافية وموفولوجية وقنوات البنكرياسفى الجمل وحيد السنام

محسد ملاح الد ين صصطفى ، محمد أحمد على ، سعبيد عمار ، على الد ين عبد الباسط

تمت هذ ه الد راسة على ستة جمال نافعة بعد تجههيزها للتشريع وكذلك تم احضار عشــــــرة

مينات من السلخانة . وقد استخد م محلول المطاط الملون وكذلك محلول سلفات الباريوم لد راسة قنوات البنكرياس باستخد أم جهاز الثعة اكس .

ولقد تم وصف البنكرياس من الناحية الطوفرافية والموفولوجية الذى ميتكون فى الجمل مــــن

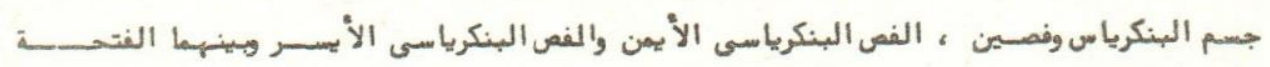
مالبنكرياسية والأخسمرة كانت كبيرة الحجسم

أُ أ عن القنوات البنكرياسية فهى تتجمع لتكون القناة البنكرياسـية الكبرى فقـط بينعا اختفـت

القناة البنكرياسية الصفرى .ولقد نوقشت النتائج مع العراجع الصتوفرة . 
Dept. of Anatomy \& Histology,

Faculty of Vet. Med., Zagazig University,

Head of Dept. Prof. Dr. A. Mobarak.

\section{TOPOGRAGHY, MORPHOLOGY AND DUCT SYSTEM OF THE PANCREAS OF THE CAMEL (CAMELUS DROMEDARIUS) \\ (W1th 4 Figures)}

By

M.S. MOSTAFA, M.A. ALY, S, AMMAR and A.E, ALY

(Received at 22/10/1981)

\section{SUMMARY}

The topography,morphology and duct system of the pancreas of Camelus dromedarius were studied. The pancrease of the camel is characterised by the presence of Corpus pancreatis, Lobus pancreatis dexter, Lobus pancreatis sinister and a wide Annulus pancreatis.

The duct system was represented by the major pancreatic duct, while the minor pancreatic duct was absent.

\section{INTRODUCTION}

The pancreas in domestic animals has been anatomically investigated by different authors due to its Importance for the wellfare of the animal body. On the other hand, literature on that organ in the camel seems to be-meagre. HEGAZI (1945) gave some morphological features on the pancreas of the camel which seems to be insufficient to give a detailed idea on such organ. However, the present investigation aims at an extended morphological knowledge on the anatomy of that organ.

\section{MATERIAL and METHODS}

Investigation was carried on six adult healthy camels preserved by the ordinary routine method of formain. In qddition, 10 specimens were brought from the slaughter houses of Zagazig, 5 of them were injected by $60 \%$ colored gum milk latex through their main pancreatic duct. The rest were also injected by radio opaque material (barium sulphate) for radiographic purposes for the duct system. Injection was carried after washing the duct with normal saline and massage was performed in order to clear out any pancreatic secreation from the duct.

\section{RESULTS}

\section{I - Topography and Morphology of the Pancreas:}

The pancreas of the camel lies on a level with the first five lumbar vertebra. It consists of two lobes ( $F$ ig. 1 and $2, b, c$ ) profecting from a flattened quadrilateral body.

Corpus pancreatis: The body is situated in the region of the porta hepatic below the first and second lumbar vertebrae. It weighs about $250-300 \mathrm{gm}$. The dorsal surface of the body lies in contact with the portal vein in its greater part, the caudate hepatic lobe and the left crus of the diaphragm.

The ventral surface is flat, related to the transverse colon. The body of the pancreas ( Fig. 2/a) is covered dorsally by peritoneum, while ventrally the peritoneal covering is difficient due to its adherence to the transverse colon by connective tissue. It measures in the adult about $10 \mathrm{~cm}$ in length and $7 \mathrm{~cm}$ in width and $1 \mathrm{~cm}$ thick.

Lobus pancreatis dexter: (Fig. 1/b, \& Fig. 2/b): It is prismatic in shape, projecting from the corresponding aspect of the body backward and to the right. It measures about $13 \mathrm{~cm}$ in length, $5 \mathrm{~cm}$ in width and $1.5 \mathrm{~cm}$ in thickness. It is contained between both layers of the mesoduodenum is related dorsally to the dorsal half of the visceral surface of the liver, the right crus of the diaphragm, the sublumbar muscles and the ventral surface of the right kidney up to level of the renal hilus. The dorsal surface presents impressions for the corresponding organs. The ventral surface is related to the transverse colon, while the medial one:is related to the hepatic lymph node, portal vein, mesenteric vein, the gastrosplenic vein and coeliacomesenteric ganglion. In about $60 \%$ of examined specimens the caudal extremity is sinuous and straight in the rest. It is 
related to the second duodenal flexure. An accessory part (Fig. 1/c) unites the right and left lobes extending from the caudal end of the right lobe to the body and intial part of the left one. Thus completing the portal vein passes to the porta hepatis. This accessory part is narrow, flattened and measures about $12 \times 1.5 \mathrm{~cm}$. The hepatic artery forms an impression on its dorsal surface.

Lobus pancreatis sinister: (Fig. $1 / \mathrm{d} \& 2 / \mathrm{c}$ ) The left pancreatic lobe, the larger of the two lobes, metisures. about $28 \mathrm{~cm}$ in length, $5 \mathrm{~cm}$ in breadth and $1 \mathrm{~cm}$ in thickness. In this respect it may exceed $1 \frac{1}{2}$ times the length of the right lobe.

It is situated obliquely along the longitudinal axis of the body between the two layers of the greater omentum, related to the rumen on the one hand and the transverse and initial part of descending colon on theother. Its cranial surface lies in contact with the medial aspect of the proximal extremity of the rumen, while the caudal one, faces backward related to the cranial msenteric vessels, the transverse and descending colon, the coeliacomesenteric ganglion, the left adrenal gland and the ventral surface of the left kidney. The caudal end of the left lobe, lies in contact with the ventral aspect of the left kidney up to the level of its hilus under the 5 th lumbar vertebra. The dorsal border is thick and the ventral one is thin.

\section{II- Duct system of Pancreas:}

Ductus pancreatis major (Fig. $3 \& 4 /$ d). The major pancreatic duct constitutes the main duct that collects the pancreatic secretion from the different parts of the pancreas. It joins the common bile duct before it terminates into the duodenum about $22-25 \mathrm{~cm}$ beyond the pyloric sphincter by an oval orifice measuring about $1 \mathrm{~cm}$ in length. It is guarded by a fold of mucous membrane giving it a valve like appearance. The ductus choledochus so formed proceeds through the wall of the duodenum as an intramural part for a distance of $6-7 \mathrm{~cm}$ towards the pylorus before it opens into the cranial duodinal flexure.

The major pancreatic duct 1 s formed by the union of two main radicles, the larger of which starts from the caudal end of the left lobe and accompany the tributaries of the venous drainage parallel to the ventral border. The other radicle is smaller and drains the right lobe. Both recleve numerous fine canalicull from the different parts of the corresponding lobe. The accessory lobe is drained by a small canal which is caudally directed then by a sharp curve turns forward to join the left duct at its middle. The convexity of this duct faces caudally. It drains the accessory, the middle and dorsal parts of the left lobe. The body of the pancreas, pours:its product directly, through 4-5 smaller canals, into the major pancreatic duct. It is observed that the accessory pancreatic duct is absent in the camel.

\section{DISCUSSION}

The pancreas was previously examined by HEGAZI(1945) who recorded a weight ranging between $1^{1}=1^{3}$ pounds (about 450 - $700 \mathrm{gm}$ ), a result which was not seen even in large adult camels in the present work. ${ }^{4}$ Moré ${ }^{4}$ ver he gave a length of about $30-40 \mathrm{~cm}$ and a breath about 5-7 cms which are nearly similar to the present $\rho$ inding.

The quadrilateral appearance of the pancreas in cattle which was recorded yb RAGHAVAN and KACHRO0 (1964) EL HAGRI (1967) and GETTY (1975) is not observed in the camel as 1t consists of a body, a long left and a short right lobes.

The ventral surface of the body lies in contact with the transverse colon in the camel which simulates that of the colt as revealed by SERGEYEVA and TREPANIER (1959).

Annulus portarum in the camel simulates that of the horse in being complete but differs in width. In the horse the portal vein is completely encircled by pancreatic tissue and Annulus portarum is only represented by the passage of the vein through the pancreas (BRADLEY, 1946; EL HACRI, 1967; SISSON and GROSSMAN, 1969, NICKEL et al., 1973, and GETTY, 1975), however in ox portal fissure was observed by RACHAVAN and KACHROO (1946) EL HACRI (1967) SISSON and GROSSMAN (1969) NICKEL et al., (1973) and GETTY (1975).

The absence of the minor (accessory) pancreatic duct and the union of the major pancreatic duct with that of the bile duct in the camel were also observed by CHAUVEAU (1891); LESBRE (1903) and HEGAZI (1945) in camel. In this respect, it resembles the pancrease of the mink as mentioned by KAINER (1954). In addition, the present 
work gave the distance from the pyloric orifice, its shape and lengh which were not mentioned before in the camel. In contrast to that of the camel RAGHAVAN and KAGHROO (1964) WASS (1965) PRADA, BORELLI and HICASHI (1966) EL HAGRI (1967) PRADA and HIGASHI (1967, 1968) PRADA (1970) GETTY (1975) in the ox and PAIVA, PRADA and NETO (1972) in the Jaffarabedi buffaloes recorded a minor pancreatic duct and the absence of the major one. On the other hand, it resembles that of the sheep and goat with regard to the pancreatic duct system (EL HAGRI, 1967 and CETTY, 1975).

As the gall bladder is absent in the camel, the termination of the pancreatic and bile ducts in the duodenum necessitates the presence of the valve like mucous fold which acts as a sphincter mechanism for regulating the flow of both secretion to the duodenum. This arrangement simulates that of the horse as observed by MILLS (1949). On the other hand BRADLEY (1946) RACHAVAN and KACHROO (1964) EL HACRI (1967), PRADA, BORELLI and FILLHO (1970) NICKEL et al., (1973) and GETTY (1975) in the horse and NETO (1977) in the donkey reported a major and a minor pancreatic duct which open separately in the duodenum a result which is not encountered in the camel. In the camel the minor pancreatic duct and the gall bladder are absent.

In one zebu bull a third pancreatic duct was present. It opens into the intestine approximately half way between the two duodenai papillae (PRADA and HIGASHE, 1968). A condition which was not observed in the present work.

\section{REFERENCES}

Bradley, 0.C. (1946): The topographical anatomy of the thorax and abdomen of the horse. Endinburgh, W. Green and Son, Limited.

Chauveau A., M.D. L.L. D. (1981): The Comparative Anatomy of the Domesticated Animals. J. \& A. CHURCHILL II, NEW Burlington St. London.

EL Hagri, M.A.A. (1967): Splanchnology of Domestic Animals 1st Ed. Cairo Univ. Press.

Getty, R. (1975): The Anatomy of the Domestic Animals. W.B. Saunders, Philadelphia, London, Toronto 5th Ed. Hegazi, A.H. (1945): Anatomy of the digestive system of the camel. Thesis M.v.Sc. Fac. of Vet. Med. Cairo University.

Kainer, R.A. (1954): The gross anatomy of the digestive system in mink. Amer. J. Vet. Res. 15, 81-90\& 91-97. Lesbre, M.F. (1903): Recherches Anatomiques Sur Les Camelld Professur d-Anatomie a L'Ecole delyon,

Milis, H.D. (1949): Speculations concerning the significance of the choledochocho-duodenal function in the horse, and its relationship to the absence of gall bladder. Vet. Rec. 61, 418-421.

Neto, P. (1977): Excretory ducts of the pancreas in the donkey. Fac. Med. Vet. Zooteonia, Univ., Sao Paulo, Brazil.

Nickel, R., Schummer, A., Seiferle, E. and Sack (1973): The viscera of the domestic animals. Verlag Pull Parey Berlin, Hamburg.

Paiva, C.M., Prada, S. and Neto, J.P. (1972): Contribution to study of the pancreatic duct system in buffaloes (bubalis-bubalis-Linnaeus, 1972) Rew. Fac. Med. Vet. Zotec. S. Paulo, 9, 43-54.

Prada, S., Borelli and Higashi (1966): Contribution to study the panceratic ducts in zebu. cattle. Arg. Inst. Biol., S. paulo, 33 (4): 125-135, (1966).

Prada, S. and Higashi, A. (1968): About the presence of the pancreatic ducts in zebu cattle. Vet. Fac. Med. Vet. S. Paulo-Vol. 7, Fasc. 4 (1968).

Prada, S. Borelli, V. and F1lho, A.F. (1970): About the comnunication of the pancreatic duct system with the duodenum, in horses. Rev. Fac. Med. Vet. S. Paulo-Vol. 8 Fasc. 2, (1970),

Raghavan, D. and Kachroo, P.(1964): Anatomy of the ox. 1st. Ed. 370 - 375. Indian Concil of Agricultural Res., New Delh1.

Sergeyeva M.A. and M. Trepanier (1959): Pancreatic morphology in higher species. Rev. Canad. Biol - 18, 59-69 (1959).

Sisson,S. and Grossman, J.D.(1969): The Anatomy of the Domestic Animals W.B. Saunders, Philadelphia and London. Wass, W.M. (1965): The duct system of th bovine and porcine pancreas. Am. J. Vet. Res. Vol. 26, No. III. 



\section{DESCTIPTION OF FIGURES}

Fig. (1): The morphology of Hancreas.

a) Corpus pancreatis.

b) Lobus pancreatis dexter.

c) Lobus accessorius.

d) Lobus pancreatis sinister.

e) Anulus pancreatis.

Fig. (2): The pancreas and its relation in situ.

a) Corpus pancreatis.

b) Lobus pancreatis dexter.

c) Lobus pancreatis sinister.

d) Ductus choledochus.

e) Part from abomasum.

f) liver.

g) right kidney.

h) Left kidney.

i) Colon

f) Spleen.

k) Dia phragm.

1) Ggl. coelfaeum and Ggl. mesentericum cranialls.

m) N. splanchnicus malor.

1) Aorta

2) A. Coeliace

3) A. gostrica dextra

4) A. hepatica

5) A. lienalis cauderlis

6) A. lienalis cranialis

7) V. portae.

Fig. $(3,4)$ : The duct system of Pancreas.
a) Porta hepatis
b) Ductus hepatis
c) Ductus choledochus
d) Duct uspancreatis major
e) Cranial duodinal flexure
f) Ductus pancreatis sinister
g) Ductus pancreatis dexter
h) Small duct drains the accessory lobe
i) Corpus pancreatis
j) Lobus pancreatis dexter
k) Lobus accessorius
1) Lobus pancreatis sinister 


列

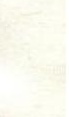



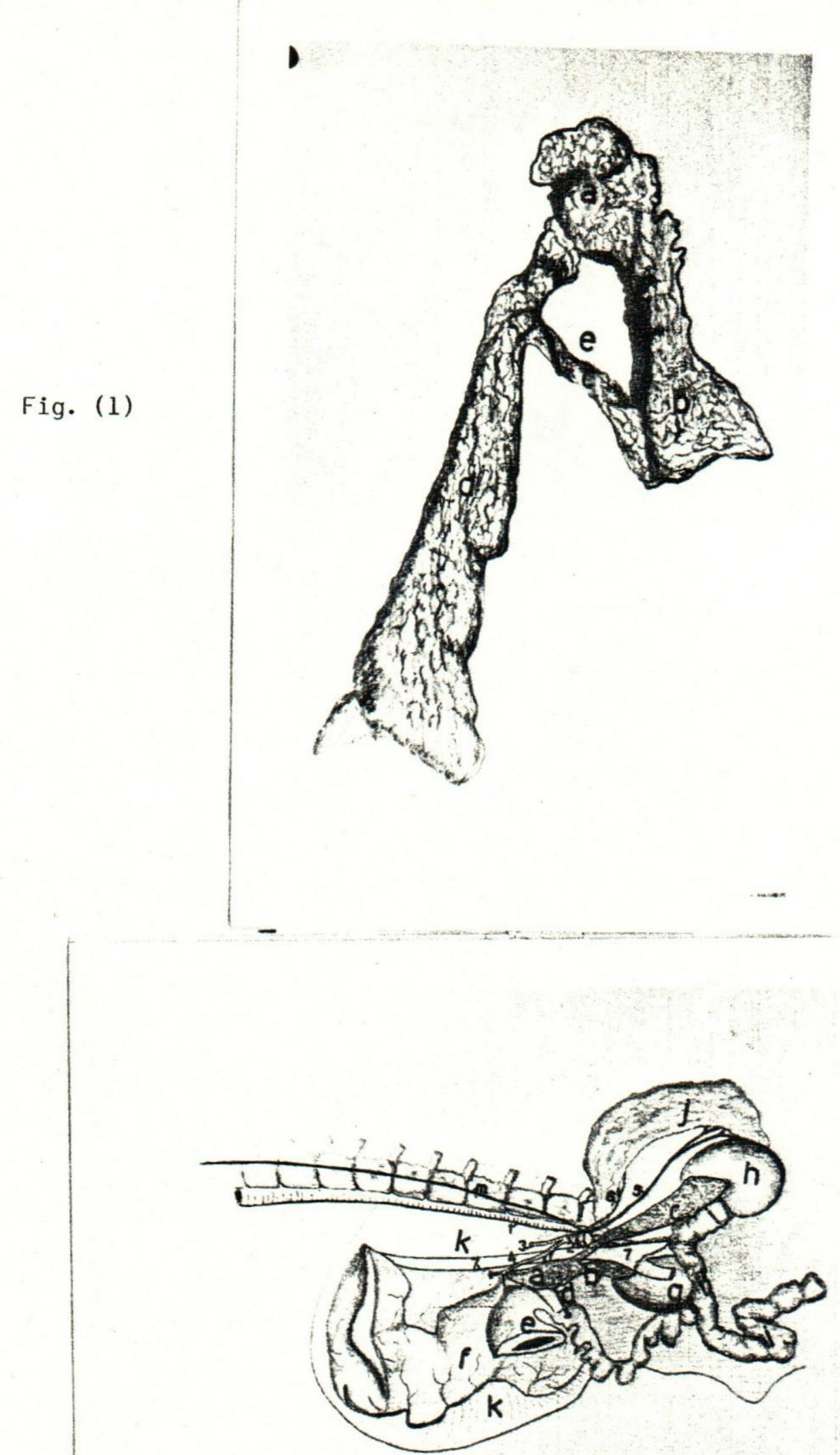

Fig. (2) 


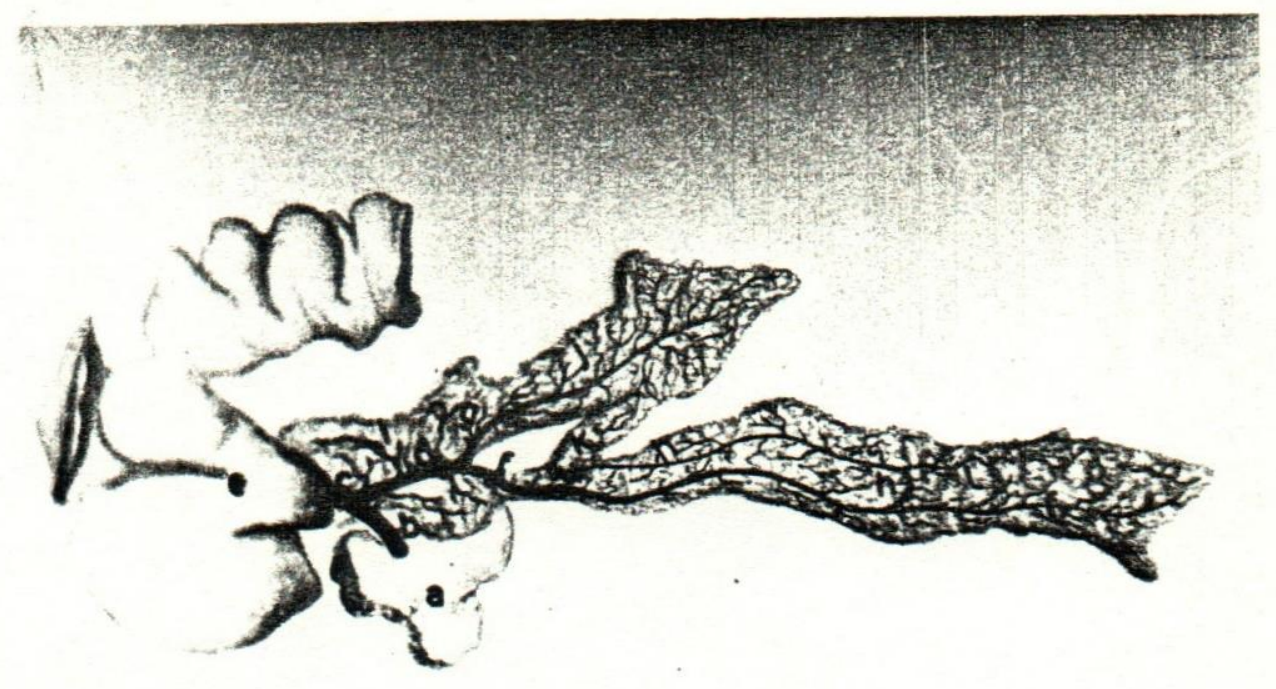

Fig. (3)

Fig. (4)

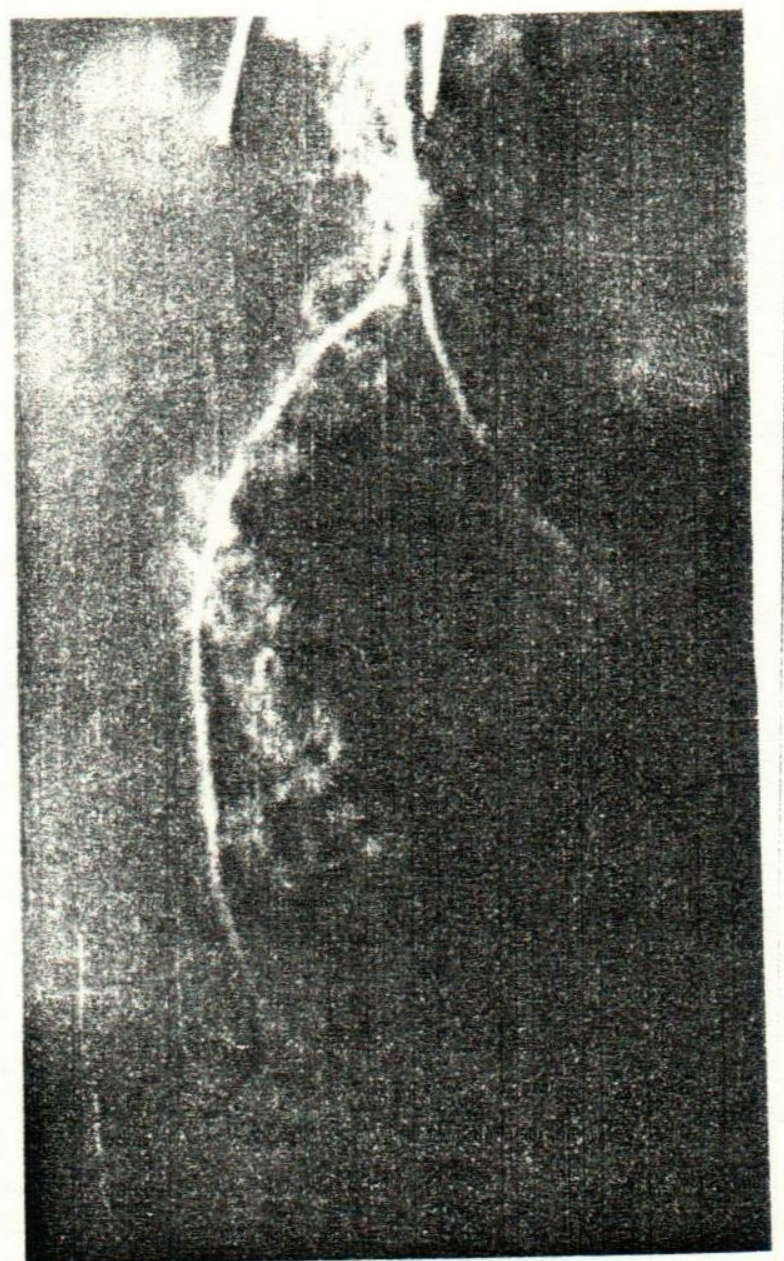


